Cahiers $d u$ MONDE RUSSE

\section{Cahiers du monde russe}

Russie - Empire russe - Union soviétique et États indépendants

$49 / 4 \mid 2008$

Destins individuels et terreur. Jeunesse dans la société post-stalinienne

\title{
Claudia Weiss, Wie Sibirien "unser" wurde
}

\section{Eva Maeder}

\section{(2) OpenEdition}

1 Journals

\section{Electronic version}

URL: https://journals.openedition.org/monderusse/6992

DOI: $10.4000 /$ monderusse. 6992

ISSN: $1777-5388$

\section{Publisher}

Éditions de l'EHESS

\section{Printed version}

Date of publication: 28 December 2008

Number of pages: $815-818$

ISBN: 978-2-7132-2197-2

ISSN: $1252-6576$

\section{Electronic reference}

Eva Maeder, "Claudia Weiss, Wie Sibirien "unser" wurde", Cahiers du monde russe [Online], 49/4 | 2008, Online since 24 December 2009, connection on 04 September 2022. URL: http://

journals.openedition.org/monderusse/6992 ; DOI: https://doi.org/10.4000/monderusse.6992

This text was automatically generated on 4 September 2022

All rights reserved 


\title{
Claudia Weiss, Wie Sibirien "unser" wurde
}

\author{
Eva Maeder
}

\section{REFERENCES}

Claudia WEISS, Wie Sibirien "unser" wurde. Die Russische Geographische Gesellschaft und ihr Einfluß auf die Bilder und Vorstellungen von Sibirien im 19. Jahrhundert. Göttingen : Vandenhoeck \& Ruprecht, 2007, 261 p.

1 Siberia is unquestionably an integral part of the Russian Federation, as it was until 1917 of the Russian Empire. From a geographic and ethnic point of view, however, the subcontinent could perfectly well form a country of its own. But conquered by the State of Muscovy in the $16^{\text {th }}$ and $17^{\text {th }}$ centuries, it became and remained a part of Russia. Why did decolonization never take place? Why did Siberia remain Russian and, unlike in Great Britain or France, why was the imperial composition of the nation preserved until this day?

2 There are many answers to these questions. By following the course of Siberian history some historians show that independence movements always remained weak and never had a chance to realize their dreams. Others have compared Siberia, the "Wild East", with the American West, and have shown how this frontier region was integrated into the Russian state. In her book How Siberia Became "Ours", the German historian Claudia Weiss implicitly argues along this line. Instead of a direct comparison with the USA, however, she formulates her guiding question in an original - and problematic - way: When and why did the Russians begin to perceive Siberia as "theirs", an integral part of their nation? Or, in her words, how did this "mental appropriation" take place?

3 In order to answer this question Weiss concentrates on the Imperial Russian Geographical Society (Weiss persistently uses the modern abbreviation RGO) and analyzes its impact on the perception of Siberia. After the introduction, the second chapter tells the story of the foundation of the RGO. In 1845 zoologist Alexander Theodor 
von Middendorf's lecture on his expedition to Siberia (1843-1845) inspired three audience members, all descendants of Baltic noble families and experienced expeditioners, to found a Geographical Society in Russia after the model of its famous predecessors in London and Paris. Originally the founding members wanted to enhance the knowledge of distant regions in general. Soon this broad interest in geography narrowed and the Russian Geographical Society chose Siberia, the largest unexplored region, as its main field of research.

An 1851 report gives further reasons for this choice by stressing Siberia's pivotal role in Russia's future:

"There is no other region in which studies would be of such practical and even of State interest than Siberia, which conceals in its depths such productive forces, waiting only for man's enterprising hands to transform them into a never-ending source of richness for the State and the Russian people. In addition, Siberia's geographical makeup constitutes one of the most important parts of the Asian continent, the study of which must be seen as one of the major tasks of Russian science, and for us as Russians with our close ties to Asia, it is an object of great interest and importance". ${ }^{1}$

5 In order to accomplish these goals, the RGO initiated and supported several expeditions through Siberia on which biologists, geographers, ethnographers and other scientists studied the practically unknown territory. A member of the Czar's family always served as president. This was, however, a rather symbolic position. The Vice-President was actually in charge of affairs.

By bringing together (in total approximately 500) members from diverse social backgrounds, the Society also served as a "place of sociability". In particular during its meetings in St. Petersburg or in the local departments, high officials and those in opposition were united in one room. It is questionable, however, whether Weiss correctly characterizes the RGO as an institution of civil society. Given the fact that freedom of thought was limited and social hierarchy fixed in the Russian Empire, could dialogue among its members really be open and could equality exist?

7 In the third chapter, "The Era of the Muravyov", Weiss shows how the RGO's scientific aims closely interlinked with the Empire's strive for expansion. Under the leadership of Vice-President Count Mikhail N. Muravyov-Vilensky, the Great Siberian Expedition (1856-1863) explored Eastern Siberia. In the same years his nephew, Nikolai Muravyov, Governor General of Eastern Siberia, annexed the Amur and the Ussuri territories for the Russian Empire. The two events didn't coincidentally happen at the same time. Originally, the expedition was supposed to explore the Kamchatka Peninsula. Nikolai Muravyov, however, convinced his uncle of the strategic importance and the economic potential of the territories along the Amur, a river that many regarded as the "Mississippi of the East." Inspired by nationalist feelings and the desire to help Russia to gain new strength after the defeat in the Crimean War, the scientists gladly worked for the needs of the motherland. Collecting hydrographical, topographic and geological information, studying natural history and physical geography, gathering data for the first complete map of the river Amur, and drawing a map of the Tatar Road, they provided the knowledge that was necessary to defend and administrate the new region.

The fourth chapter "Against the Empire" deals with the numerous members of the RGO that were punished for political reasons and exiled to Siberia. Among them were the visitors of Petrashev's circle that were accused of planning a conspiracy, participants of the Polish uprisings, the anarchist Peter Kropotkin and the regionalists N. Jadrincev and 
Potanin. Wise enough not to include their statements in the protocols of the Society's meetings, the RGO still let them express their opinions, sent them books and allowed them to do research in the Society's name. Thus, it not only lightened their burden of exile but also helped them to deploy their knowledge in the service of the Empire.

In the 1870s, the RGO closely collaborated with Imperial officials and entrepreneurs in order to develop routes on land and water, to construct telegraph lines and plan a railway network throughout the Russian Empire (chapter five: "In the Service of the Empire: the RGO's activities in the field of economics and infrastructure"). In the projection and realization of these projects, Vice-President Petr Semyonov played an important role. Being a pioneer of statistics and, as Weiss argues, Russia's first economic geographer, he brought together scientists, business-minded financiers and the decisionmakers in the ministries. Together the representatives of these "interest groups" realized three pivotal enterprises: the levelling of Siberia, the development of an inner-Siberian waterway and the construction of the Great Siberian Railroad after 1892. They all helped to better connect Siberia with the European part of the Empire which facilitated stronger political unification, better access, more efficient administration, economic development and social improvements.

Apart from its specific missions in the fields of science, economics and infrastructure, the RGO made the value of Siberia known to the public at home and abroad. In Russia, it donated the objects that the scientists had collected to museums. There, they helped visitors develop concrete images of a region that most Russians knew previously only from books and oral reports. The last chapter of the book presents the three different channels that the Society used in its international presentations. First, it sent its representatives to statistical and geographical conferences and furnished exhibits to the exhibitions that accompanied the latter. The numbers that Weiss presents are impressive: in Paris in 1875 12,000 visitors had the chance to see almost 600 exhibits provided by the RGO. Secondly, it helped the state officials to prepare Russia's presentations on the universal exhibitions where the Empire participated regularly since 1867. With up to 50 million visitors on the World Fair in Paris 1900, these events operated on an even larger scale. The crowds were confronted with a similarly large number of exhibits, in Paris there were several thousands from Russia alone. The objects from Siberia - maps, pictures, minerals, but also a richly ornamented cast iron pavilion and a simulation of the Great Siberian Railroad - documented the huge size, wealth and political strength of the Russian Empire. Moreover, by creating the image of an exotic and barbarian Siberia, they allowed European Russia to appear more civilized.

The third channel that the RGO used to propagate the value of Siberia were its publications, the monthly journal "Zapiski Sibirskogo Otdela RGO" as well as a broad range of books and brochures. By comparing several articles in detail, Weiss shows how the image of Siberia changed. An utter wilderness at the beginning, it turns into a land of the future during the $19^{\text {th }}$ century. The RGO's publications enjoyed a good reputation, they were read even abroad, translated and reprinted in Western periodicals, such as the German Mittheilungen aus Justus Perthes' Geographischer Anstalt (later renamed in Petermanns geographische Mitteilungen). Possibly, they also provided the information that Jules Verne used in his novel The Courier of the Czar.

12 The collection, discussion and propagation of information and the preparation of infrastructural projects helped to better integrate Siberia in the Russian Empire. It is Weiss' merit that the RGO's important role in this process becomes visible. She also 
points to a linguistic indication of a new perception of Siberia: in the $19^{\text {th }}$ century, members of the Russian Elite started to speak of Siberia as "nasha", ours. The economic potential of the region was certainly one of the causes of this shift. The question of how the appropriation took place on a mental level, however, remains abstract. In order to be answered, the other institutions and individuals that were responsible for the appropriation - such as the government, entrepreneurs, tradesmen, the army - need to be considered as well. Also, one could ask how the incorporation of Siberia in the Russian Empire in the second half of the $19^{\text {th }}$ century was related with its mental appropriation by the Russian Elite. Did not the migration of more than five million peasants to Siberia after 1861 and the russification policy of the czars' also contribute significantly to this process ? Finally, considering the importance that the government had in the appropriation of Siberia, it is irritating that high officials have been assigned to the wrong institutions (S.S. Uvarov was Minister of Education and not Minister of the Imperial Domains, A.G. Jomini was Ministerial Council and not Minister of Foreign Affairs). What concerns the RGO and its activities in Siberia, however, Weiss' book is most instructive and entertaining. Thanks to a broad range of quotations from diverse documents, the spirit of exploration and conquest that dominated the $19^{\text {th }}$ century comes alive.

\section{NOTES}

1. The English translation of this quote is cited in Claudia Weiss, The Meaning of Siberia for Russian Imperial Identity, p. 15 (unpublished manuscript). 